\title{
8
}

\section{Integrating Transition Processes for Regenerating the Greyfields}

\section{Introduction}

There is currently a deficit in urban planning associated with the future development of greyfields. Strategies designed to encourage the transition to more-compact cities by directing development and population inwards and upwards rather than outwards are not performing as expected. Brownfield development has accelerated, as reflected in the growth of inner-city apartments. However, new housing development in greyfields is underperforming. Higher-density housing development in designated activity centres and on transport arterials is lagging. These established planning approaches are necessary strategies but not sufficient, as they are being undermined by statutory planning regulations governing residential redevelopment in greyfield suburbs. Piecemeal and fragmented smalllot subdivision via knock-down-rebuild has become the principal vehicle for housing redevelopment in the established ageing middle suburbs because they are all that the existing planning schemes permit. This suboptimal model is readily accommodated by developers, especially small contractors, within the existing residential zoning systems that preside over low-density suburbia, providing $1: 1$ and between 2:1 and 4:1 
redevelopment. Because of these land-use planning policies, most new housing construction continues to be pushed into the poorly serviced peri-urban greenfields despite strategic plans that incorporate initiatives to curb urban sprawl, and despite heavy demand for well-located, higherdensity housing, especially in high-amenity suburbs such as greyfields.

This book advocates for the introduction of GPR as the guide to future urban development in the middle suburbs. Two new, linked models of greyfield regenerative urban redevelopment need to be part of the palette of metropolitan planning strategies and statutory processes: place-activated and transit-activated GPR. The process for change needs to begin by recognising the appropriate locations in greyfields areas for intervention (which cover about $40 \%$ of most Australian cities) and undertake district greenlining to establish more specific spatial targets for new GPR projects.

The planning principles set out in this book can be summarised as:

- Halting car-dependent urban sprawl, with its associated negative economic, social, and environmental impacts through strategic plans promoting the growth and regeneration of 20-minute neighbourhoods in greyfields

- Replacing the present redevelopment method set out in planning schemes that encourages small-lot subdivision or one-for-one redevelopment, and that is no longer functional

- Redeveloping at larger scale with GPR projects in well-located, wellserviced greyfield suburbs where there is high redevelopment potential

- Using twenty-first-century technologies and net-zero planning processes to significantly reduce the high ecological footprints associated with carbon emissions, water use, and waste generation

- Ameliorating local climate-change impacts at the same time with naturebased solutions involving redesign, greening, and reactivation of local streetscapes and residential precincts

Figure 8.1 shows this combination of key urban planning principles and charts the direction for future sustainable urban development policy and planning.

Achieving these interventions_-reshaping, remaking, redeveloping, renewing, retrofitting, regenerating - is challenging and will require new 


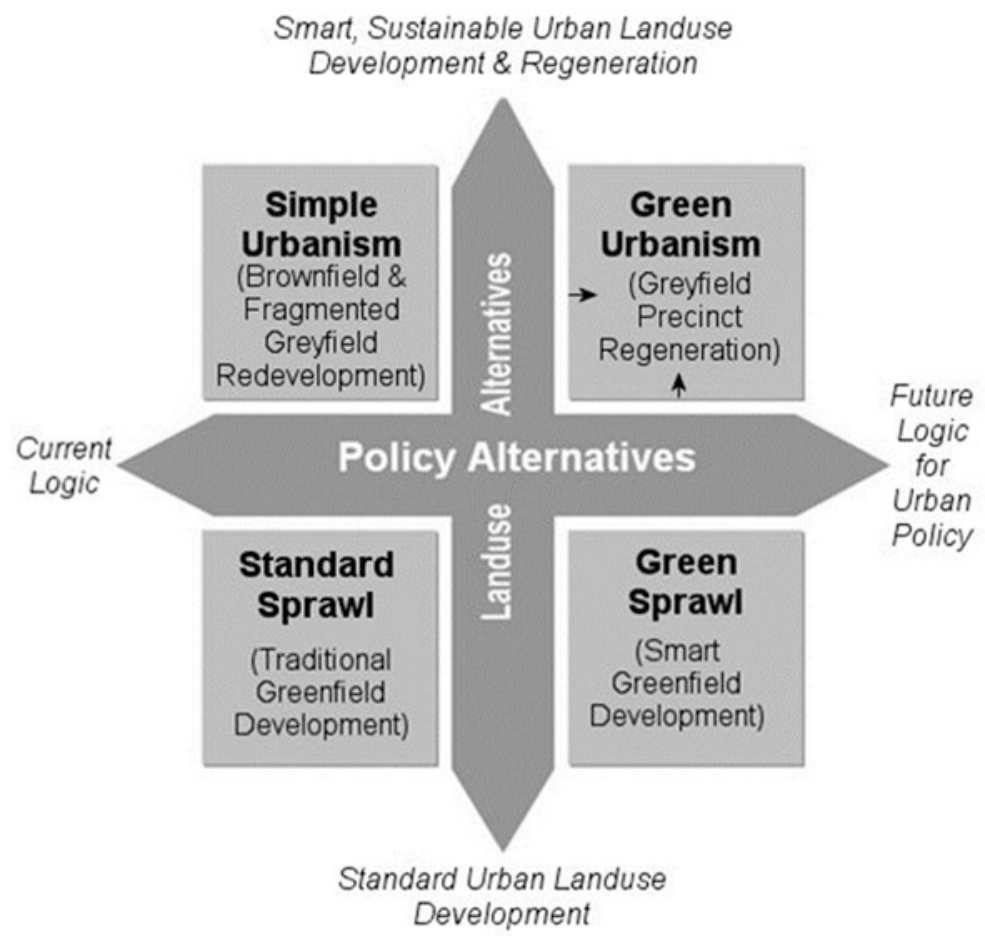

Fig. 8.1 Green urbanism-the planning logic for GPR. (Source: Adapted from Newton et al., 2011 and Newton \& Glackin, 2014, including elements of a keynote presentation by P. Schwarz (Global Business Network) on Sustainable and High Growth Cities, World Cities Summit, Singapore, 29 June 2010)

urban land-use planning policies and innovative precinct-scale regenerative urban design processes and regulations, as outlined in the previous chapters. Their transition challenges are highlighted in the following sections.

\section{Making the Transition: What Needs to Change}

Table 8.1 outlines the 10 Transitions introduced in Chap. 1 with a précis of the innovations required to advance them that are outlined in this book. 
Table 8.1 GPR transition challenges and pathways

\begin{tabular}{l} 
Transition challenges \\
\hline Transition 1. Urban fabrics: \\
retrofitting automobile- \\
dependent suburbs with walking- \\
city and transit-city transport \\
infrastructures at higher levels of \\
residential redevelopment.
\end{tabular}

Transition 2. Urban forms: increasing provision for mediumdensity housing in established greyfield suburbs, employing innovative transit-activated and place-activated GPR redevelopment models at precinct scale.

\section{Transition 3: Urban spatial} structures: developing a metropolitan plan for morecompact twenty-first-century cities, which are capable of delivering sustainable urban development that is productive, resilient, liveable, and inclusive.

Transition 4: Meshing housing and household life cycles for optimal residential redevelopment: developing a planning and zoning scheme that supports more agile and forward-looking planning of residential redevelopment in greyfields to enable precinct-scale, mediumdensity projects yielding more housing, more sustainably.

Pathways to transition

Transit-activated GPR can enable a high-quality transit option along a major road or tram corridor incorporating mixed-use station precincts with walking-city character. Auto-dependent suburbs with high redevelopment potential can use place-activated GPR to recreate neighbourhoods with mediumdensity housing and more local transport options involving new-technology electric shuttles, scooters, and bikes to link to nearby activity centres, and to trains and trams.

Standard planning approaches will not work until strategic district greenlining of urban districts becomes the spatial framework for transit-activated and/or place-activated GPR projects; in other words, until the density, mixed-use, and infrastructure requirements and regulations are changed to create precinct-scale regenerative redevelopment opportunities at medium density.

Planning priorities at all three levels of government need to focus on greyfield regeneration for multiple benefits and meeting economic, equity, community, and sustainability goals. A clear metropolitan strategy is needed for each city that identifies the greenlined zones where GPR can be attracted.

New zoning needs to be mandated in designated areas that enable GPR by prescribing minimum lot sizes for infill development (necessitating lot amalgamation) as well as incentivising consolidation among neighbouring property owners. This process can be enabled by district greenlining and partnerships leading to successful transit- or place-activated GPR projects. 
Table 8.1 (continued)

\begin{tabular}{|c|c|}
\hline Transition challenges & Pathways to transition \\
\hline $\begin{array}{l}\text { Transition 5: Changing household } \\
\text { structures and composition: } \\
\text { fostering a property- } \\
\text { development industry capable of } \\
\text { matching demand from an } \\
\text { increasing diversity of household } \\
\text { types and life-cycle stages with } \\
\text { supply of more affordable and } \\
\text { diverse types of housing. }\end{array}$ & $\begin{array}{l}\text { Government agencies need to set up more } \\
\text { demonstrations with innovative } \\
\text { developers who can meet changing } \\
\text { demographic demand as well as provide } \\
\text { affordable housing in greyfield areas, } \\
\text { especially in designated GPR projects. } \\
\text { Government can also demonstrate } \\
\text { leadership in public housing estate } \\
\text { renewal by jointly regenerating housing } \\
\text { and neighbourhoods. Training programs } \\
\text { in planning for greening greyfields will } \\
\text { be needed. }\end{array}$ \\
\hline $\begin{array}{l}\text { Transition 6: Overcoming the } \\
\text { problems with sprawl: smart, } \\
\text { sustainable metropolitan } \\
\text { development strategies are } \\
\text { needed for transformative } \\
\text { change to occur at building, } \\
\text { precinct, and city levels that can } \\
\text { help prevent further car- } \\
\text { dependent urban sprawl that } \\
\text { continues to erode most } \\
\text { elements of sustainability. }\end{array}$ & $\begin{array}{l}\text { Metropolitan strategic planning needs to } \\
\text { establish clear growth boundaries with } \\
\text { no incentives for further peri-urban } \\
\text { developments, unless connected to } \\
\text { public transit; at the same time, } \\
\text { metropolitan districts where } \\
\text { redevelopment and infrastructure } \\
\text { retrofitting is to be focused need to be } \\
\text { identified through district greenlining to } \\
\text { form a macro-planning context for } \\
\text { brownfield and greyfield regenerative } \\
\text { precinct development. }\end{array}$ \\
\hline $\begin{array}{l}\text { Transition 7: Transitioning } \\
\text { metropolitan planning strategies } \\
\text { linked with urban infill: this } \\
\text { needs to shift from alignment } \\
\text { with suboptimal urban } \\
\text { redevelopment models and } \\
\text { processes built into the current } \\
\text { planning system in most } \\
\text { redeveloping car-dependent } \\
\text { cities and needs reviewing at all } \\
\text { planning levels and functions. }\end{array}$ & $\begin{array}{l}\text { All municipal and state government } \\
\text { strategic and statutory planning } \\
\text { guidelines that are continuing to be } \\
\text { applied in middle suburbs need to be } \\
\text { revised so that they no longer give rise } \\
\text { to suboptimal, low-quality subdivisions; } \\
\text { and guidelines for what can replace } \\
\text { them need to be developed and trialled } \\
\text { in high-quality GPR demonstrations. }\end{array}$ \\
\hline
\end{tabular}


Table 8.1 (continued)

\begin{tabular}{ll}
\hline Transition challenges & Pathways to transition \\
\hline $\begin{array}{l}\text { Transition 8: Overcoming the } \\
\text { failure of current urban infill }\end{array}$ & $\begin{array}{c}\text { GPR policies and strategies have been } \\
\text { developed as a response to this deficit }\end{array}$ \\
$\begin{array}{l}\text { strategies to achieve sustainable } \\
\text { redevelopment and targeted }\end{array}$ & with demonstrations beginning to \\
housing yields: most & happen. Building on success will \\
metropolitan planning in the & accelerate the transition to GPR and \\
greyfields needs to move on from & remove the sense of planning failure. \\
a constant failure to deliver the & The more that community engagement \\
kind of housing and transport & will be the solutions that are developed \\
outcomes that are set in their & for a range of different precincts with \\
strategic plans. & different contexts. \\
Transition 9: Redefining the & All zoning and other statutory regulations \\
'missing middle' in housing and & that are used to subdivide property in \\
urban redevelopment: from & established middle suburbs now need a \\
medium-density housing on & clear timetable to transition to \\
small-lot subdivisions to medium- & mandated precinct-scale regenerative \\
density, precinct-scale & developments (transit- and place- \\
regenerative redevelopment. & activated GPR) guided by a future district \\
& greenlining process centred on \\
infrastructure retrofitting, residential \\
Transition 10: Providing a precinct & The provision of precinct-scale housing by \\
planning. & developers, and precinct-scale \\
& technology and infrastructure by all \\
& utilities, needs to become the \\
& mainstream process in greyfield \\
regeneration, and eventually to move & into all other parts of the city. \\
\hline &
\end{tabular}

\section{The Need for Partnerships}

Fundamental to the processes outlined in Table 8.1 is the need for partnerships. In all GPR projects, whether transit- or place-activated, there will be no precinct-scale land assembly followed by detailed delivery of the necessary land development unless government, community, and developers are working together. This was very clear in the Maroondah demonstration project (Chap. 7) and other demonstrations such as WGV 
(Chap. 4). Such partnerships need governance frameworks and instruments to enable co-creation of regeneration strategies, plans, and projects.

Figure 8.2 identifies the necessary governance/partnerships space, with key stakeholder groups.

These partnerships all have their specific roles, as identified in Fig. 8.2. GPR projects could start with an initiative from any one of these stakeholders - the three levels of government, innovative businesses,

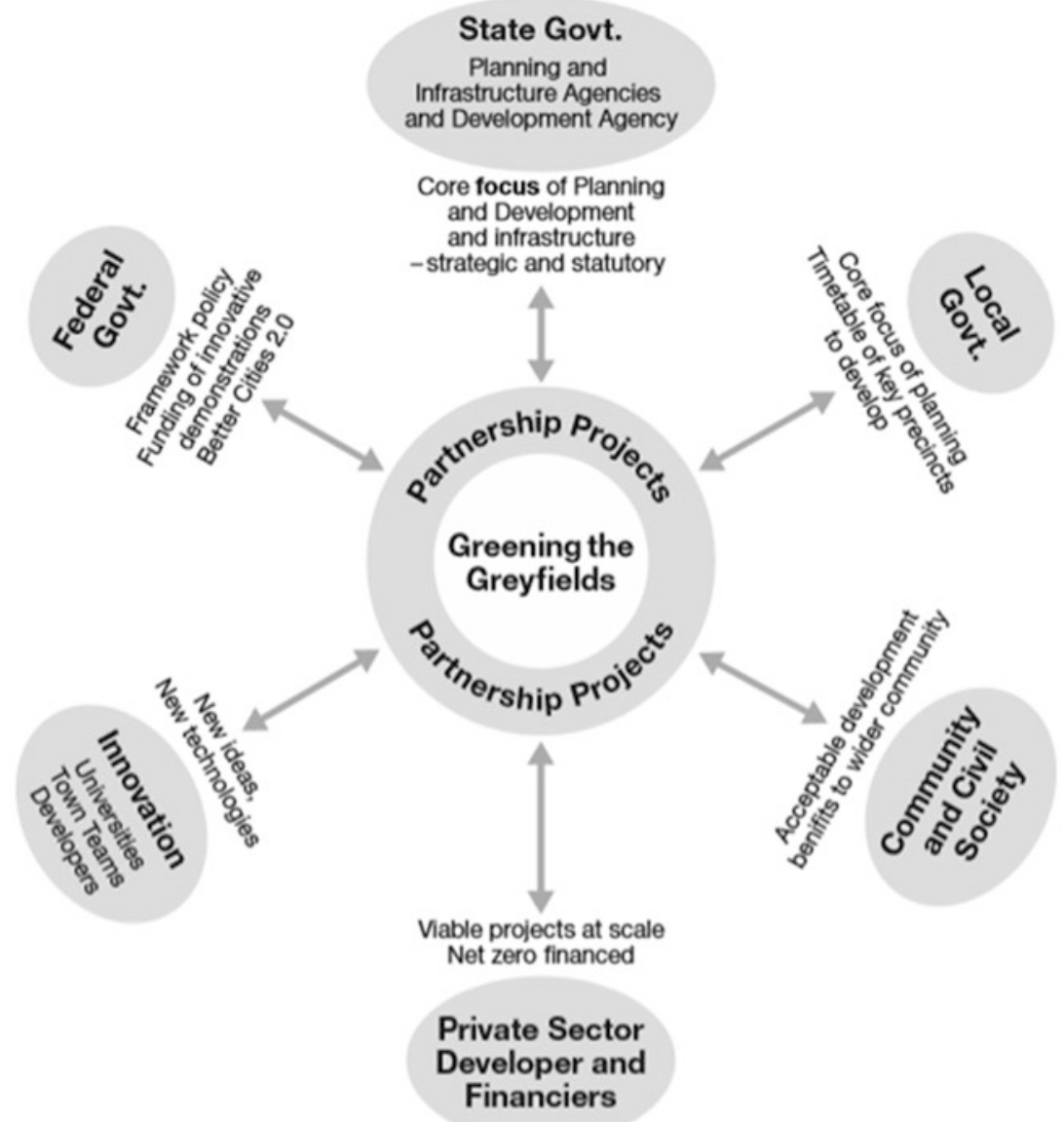

Fig. 8.2 Partnerships needed for GPR 
mainstream financiers and developers, and the community. But they will all be needed at some point to accomplish GPR. Engagement and integration are therefore key, and they require partnership governance processes to commence from the moment that a new GPR project is envisaged.

The Building Better Cities Program in the early 1990s in Australia was a federal government program that set up a partnership process and a new model for redeveloping brownfield precincts across all cities. The federal government provided leadership and seed funding and oversaw development of projects involving state and local governments and industry that multiplied the initial seed investment (Neilson, 2008; Sharma \& Newman, 2020; Thomson et al., 2017; Newton \& Thomson, 2017; Newton, 2018). These pioneering inner-city brownfield regeneration projects had little community involvement, as they were largely on old industrial or abandoned port sites. In today's greyfields it would not be possible to imitate this model without significant community engagement. In greyfields, current top-down planning no longer works effectively; nor does simple bottom-up planning. The required partnership process is not linear; rather, it needs to be seen as a system that can be set in motion from any point but must eventually bring all its facets into a journey that lets them work creatively together.

Some of the key interactions that need partnerships to help deliver GPR are set out below.

\subsection{Residents/Community}

- Approximately half of all residents located in greyfield suburbs (Chap. 6) revealed a preference for medium-density living in welllocated neighbourhoods over a separate house in a car-dependent suburb. However, the other half generally did not want any change to their situation, and without any engagement would be more than likely to establish NIMBY groups.

- The transition from NIMBY to YIMBY requires overcoming the community resistance of homeowners in established low-density suburbs to a more 'urban' future by arguing for a better future by demonstrat- 
ing the community additionalities to residents in greenlined 'change' areas. Regenerated greyfield precincts need to be places where people want to live.

- There is thus a need to make the lot-amalgamation process less risky among neighbours in selected greenlined districts where GPR overlays are being proposed. This will involve innovative forms of engagement in 'town hall' and 'kitchen table' settings with residents as every step of the precinct-regeneration process is co-created.

\subsection{Innovators/Urban Designers}

- Innovators can be involved in the technology or design side of urban development, and often larger innovative architectural/planning firms are where these new technologies and bolder design concepts are integrated and trialled. Research institutions are also part of this process. However, most greyfield development is currently done by small builders who don't engage architects (less than 5\% of all new housing in Australian cities directly involves professional architects). Instead, small builders tend to use the same project-home model for many years. There is a lack of innovation.

- Innovators have a critical role to play in shaping cities in more sustainable and liveable ways. The GPR process should encourage this, perhaps through the procurement process in a formal way; certainly in the early stages they need to inform local governments and communities about what is possible and feasible. In the second quarter of the twentyfirst century, there is a dearth of easily accessible and navigable knowledge hubs containing information validated by science and industry for the architecture, engineering, and construction sector.

- Poor design with minimal innovation can begin to be overcome through Medium Density Design Guides and State Government Architect-initiated 'missing middle' design competitions that can raise the sights of developers and the community: https://www.epw.qld.gov. au/about/initiatives/density-diversity-competition. 
- Perhaps of more importance is to shift from prescriptive to performancebased building and planning codes for GPR; this enables more innovative design but requires transparent performance assessment, an area currently in deficit (Newton, 2019).

A range of innovative Toolkits exists to assist with precinct performance assessment and visualisation. Many of these have been developed in Australia by the Cooperative Research Centre for Low Carbon Living (Newton \& Taylor, 2019) and the Cooperative Research Centre for Water Sensitive Cities (in particular two of their Integrated Research Projects: Water-Sensitive Urban Infill and Economic Evaluation of Nature-Based Services; https://watersensitivecities.org.au/). Nextgeneration versions of these tools will be integrated within a Precinct Information Modelling framework now emerging (Fig. 8.3; Newton et al., 2018), capable of being employed on national digital collaboration platforms to drive the acceleration and mainstreaming of precinct-scale planning and design (Newton \& Frantzeskaki, 2021).

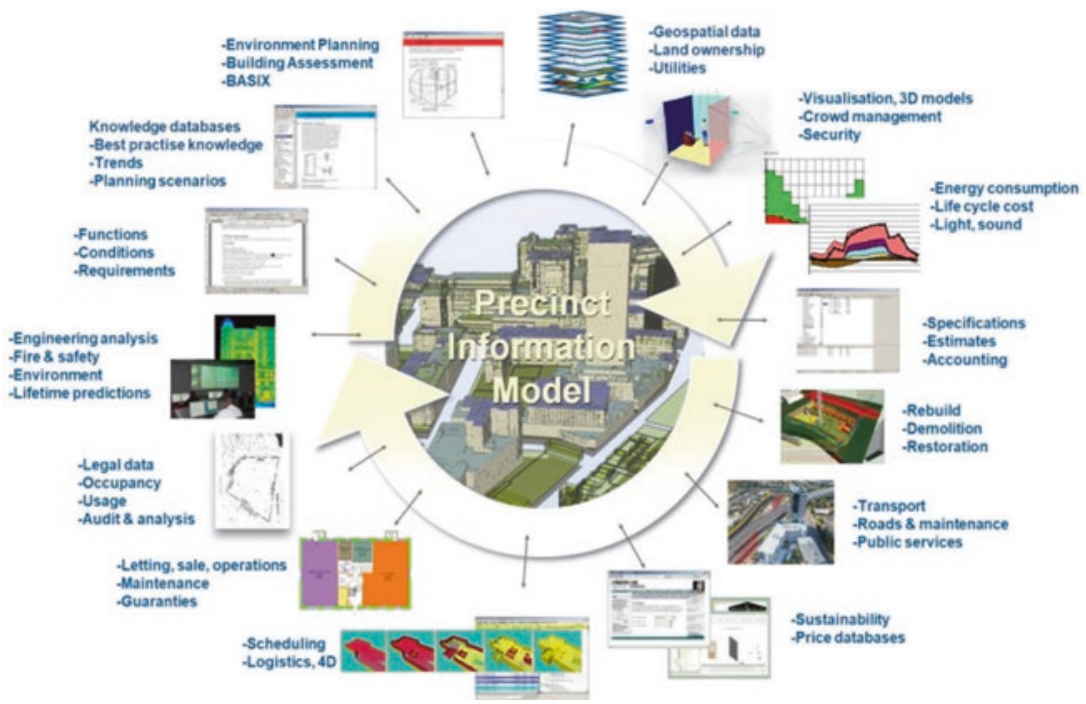

Fig. 8.3 Precinct Information Model-integrating and accelerating the precinct design process. (Source: Plume et al., 2019) 


\subsection{Urban Developers/Communities and Civil Society}

- Developers play a critical role in demonstrating innovation in all aspects of building and construction (including modular construction, selection of more sustainable circular economy materials, and net-zero buildings), as well as implementing precinct design that is attractive to the market and available at different price points. As outlined in Chap. 7, GPR needs a different type of developer to those currently operating in the market (Chandler, 2018). New partnerships will play a role in this process.

- Establishing a new GPR business model for those property developers who do not yet have a GPR mindset is likely to be necessary before GPR will be delivered effectively. This will need to accommodate town-hall and kitchen-table engagement for lot consolidation, codesign and co-development with property owners and local council, and all the other innovations suggested in this book on how to use new technology to deliver more sustainable and affordable twenty-firstcentury urban environments.

- New groups are being formed, such as Town Teams (https://www. townteammovement.com/), which seek to represent community values in establishing better redevelopment outcomes. Partnerships with such groups and research organisations can provide world best practice to lead partnership discussions that go beyond the industry associations and professional bodies that currently represent developers and builders, and that often settle for business-as-usual outcomes.

- Unsolicited bids for greyfield regeneration in larger precincts, or even whole corridors, along with substantial innovations in local and corridor transport, can be a good solution for some areas where government has not seen the potential for such innovation. Government can still provide incentives for common-good outcomes and use the benefits of partnership to assist with funding in other projects that learn from such innovative partnerships. 


\subsection{Federal/State/Local Government}

- The greyfield redevelopment challenge is common to all major cities in Australia as well as globally. The current deficiencies described in this book do not represent a traditional 'market failure' per se, as there has been a failure on the part of governments at all levels as they shy away from the necessary but challenging urban-planning models and interventions that are the focus of this book. There is a clear planning deficit that requires a response.

- The Australian Constitution established that state and territory governments have principal responsibility for planning and land management whilst delegating most planning delivery to local government. This is the case in most similar jurisdictions across the world. State governments have created specific authorities tasked with developing the planning, design, and governance arrangements needed to transform parts of their cities. This has included greenfields (e.g., Growth Area Authorities), brownfields (e.g., Docklands Authority, Barangaroo Authority), and urban land authorities for developing government land. However, no authority or agency has responsibility for greyfield regeneration. This needs to change (Box 8.1).

\section{Box 8.1 Greyfields Precinct Regeneration Authority}

In 2020, the Property Council of Australia launched a strategy paper to discuss the principles they considered underpinned successful precincts and how they can be enabled through public- and private-sector strategic planning, policy, partnerships, and engagement (PCA, 2020). The five critical elements included a shared vision and understanding between government and industry about: (1) the need for a well-resourced precincts authority to streamline development and foster positive outcomes; (2) the features that enable the delivery of successful precincts; (3) new planning processes that carve out a clearly defined role for precincts as vital infrastructure; (4) the role of the private sector in determining a site's precinct development potential; and (5) the role of government in the timely delivery of vital infrastructure to enable the success of precinct developments. The focus of this paper along with discussions associated with a Precincts Authority was large-scale precinct projects such as National Employment and Innovation Clusters. Extensive greyfield precinct redevelopment of a scale that is a 


\section{Box 8.1 (continued)}

focus of this book was not in the PCA's scope, being primarily economicoriented. Planning authorities require a balanced set of objectives: social, community, and environmental as well as economic. Surely it is time that a Greyfields Precinct Regeneration Authority, first advocated a decade ago in the context of greyfield regeneration (Newton et al., 2011), is established that can help create the partnerships necessary to deliver GPR projects.

State governments are also providers of public housing (currently 3-5\% of total housing stock), dating back to the mid-twentieth century, when major estate programs were established. This stock has aged and now is primarily in greyfields, and represents a major opportunity for governments to lead by example in initiating precinct-scale housing and neighbourhood regeneration. They own all the property, so there is no challenge of consolidating sites. Murray et al. (2013) has documented the deficiencies of private industry's piecemeal redevelopment of individual public-housing properties in response to a federal injection of major GFC funding, and the more recent proposal to sell parcels of public housing property for private-sector redevelopment in a public housing estate renewal program has led to a major government inquiry and remains problematic (Kelly \& Porter, 2019). A superior precinct regeneration approach for greyfield public housing estate redevelopment (dwelling plus streetscape redesign) has been established by AHURI (Murray et al., 2015).

- Local governments will always be the first step in the chain of how communities relate to urban development. If GPRs begin to happen through state and federal initiatives or unsolicited bids from developers, local government will need to develop greater capacity for managing development at the precinct scale and guiding the associated local community engagement processes to enable good local outcomes. This highlights the need for a Greyfield Precinct Regeneration Authority capable of assembling the transformative capacity (specialist skills and tools) that can assist with district greenlining as well as key GPR project processes where municipal governments need assistance. 
- The Australian federal government has a long history of avoiding responsibility for city planning and development, apart from a short period between 1991 and 1996 when the Deputy Prime Minister established the Building Better Cities programme (Neilson, 2008). There is now a Ministry with responsibility for cities after Prime Minister Malcolm Turnbull 30 years later sought to show leadership in this area-something that has bi-partisan political approval. There is, therefore, an opportunity for the national government to lead a Better Cities 2.0 Partnership to inject much-needed urban regeneration into the greyfields of Australian cities.

\section{$4 \quad$ Getting Started}

A key message in this book is that the goal of achieving green urbanism in greyfields is fundamentally a problem of planning, not design, politics, lack of investment, or lack of demand from people looking for better 'living arrangements' (dwelling and location combinations). We are suggesting new ways to do planning that may help. Chapter 7 presented a detailed example of a new GPR planning process in Melbourne. It established a process for engaging the key stakeholders listed in Fig. 8.2 in all the stages required to deliver a GPR project. However, there remains the challenge of achieving a greater level of understanding among stakeholder groups (and especially in the community) to assist with gaining broader political acceptance of planning that enables the greening of the greyfields.

The key concepts of both transit- and place-activated GPR and district greenlining are core to the vision of greyfield regeneration. Mainstreaming what was pioneered in the City of Maroondah is the transformative process that lies ahead.

\section{Conclusion}

The middle suburban greyfields are in trouble in Australian cities and many other cities around the world. This book has developed the concept of greyfield precinct regeneration with two models for planning and 
development, both of which are necessary: transit-activated and placeactivated GPR. There are many issues associated with design for such precincts that are not new (principles of good precinct design are well established but not yet fully realised in on-the-ground projects), and there are many emerging opportunities resulting from twenty-firstcentury distributed urban technologies that target the precinct scale, as discussed in this book. There are, however, many planning issues that are simply not being addressed, as much of the planning system for greyfields defaults to the delivery of suboptimal small-lot subdivisions that do not halt urban sprawl. They are simply not coping with the demand for new housing and the need for more regenerative redevelopment in greyfields.

A fundamental need is to find a mechanism for stimulating land assembly with the local community within a well-established and accepted strategic planning process so that precinct-scale regenerative redevelopment can be realised instead of single-lot subdivision. District greenlining has been advanced as a necessary strategic planning process that enables the boundaries of larger districts to be identified where retrofitting timetables for next-generation energy, water, waste, transport, and nature-based infrastructures are planned in an integrated manner, providing the spatial context for individual place- and transit-activated GPR projects. This enables the beginning of a process of discussion about the potential for landowners to become positive agents for change and finding better outcomes in such areas, whether that involves selling and leaving or wanting to stay and become a 'partner' in a GPR project. This indicates that engagement with local residents to establish win-win partnerships will be the critical step that can unlock the possibilities of greyfield regeneration.

When design, planning, and engagement are integrated into a vision for greening the greyfields, the serious rebuilding of the greyfields can begin. It is a unique twenty-first-century opportunity. Urban regeneration represents the chance to usher in a new restorative economy capable of significant wealth generation and job creation (Cunningham, 2008), as well as a green economy where new technologies and the achievement of goals for sustainable urban development are central to societal progress (Newton \& Newman, 2015), setting Australia's cities up for a better future. 


\section{References}

Chandler, D. (2018). Why have we failed to implement a viable missing middle strategy? The Fifth Estate, June 26.

Cunningham, S. (2008). ReWealth: Stake your claim in the $\$ 2$ trillion redevelopment trend that's renewing the world. McGraw-Hill.

Kelly, D., \& Porter, L. (2019). Understanding the assumptions and impacts of the Victorian Public Housing Renewal Program. Centre for Urban Research, RMIT University.

Murray, S., Bertram, N., Khor, L.-A., Rowe, D., Meyer, B., Newton, P., Glackin, S., Alves, T., \& McGauran, R. (2013). Design innovations delivered under the Nation Building Economic Stimulus Plan-Social Housing Initiative. Australian Housing and Urban Research Institute Limited.

Murray, S., Bertram, N., Khor, L.-A., Rowe, D., Meyer, B., Murphy, C., Newton, P., Glackin, S., Alves, T., \& McGauran, R. (2015). Processes for developing affordable and sustainable medium-density housing models for greyfield public housing precincts. Australian Housing and Urban Research Institute Limited.

Neilson, L. (2008). The 'Building Better Cities' program 1991-96: A nationbuilding initiative of the Commonwealth Government. In J. Butcher (Ed.), Australia under construction: Nation-building past, present and future (pp. 83-118). ANU Press.

Newton, P. W. (2018). Framing new retrofit models for regenerating Australia's fast growing cities. In M. Eames, T. Dixon, M. Hunt, \& S. Lannon (Eds.), Retrofitting cities for tomorrow's world (pp. 183-206). Wiley-Blackwell.

Newton, P. (2019). The performance of urban precincts: Towards integrated assessment. In P. Newton, D. Prasad, A. Sproul, \& S. White (Eds.), Decarbonising the built environment: Charting the transition (pp. 357-384). Palgrave Macmillan.

Newton, P., \& Frantzeskaki, N. (2021). Creating a national urban research and development platform for advancing urban experimentation. Sustainability, 13,530 .

Newton, P., \& Glackin, S. (2014). Understanding infill: Towards new policy and practice for urban regeneration in the established suburbs of Australia's cities. Urban Policy and Research, 32(2), 121-143.

Newton, P., \& Newman, P. (2015). Critical connections: The role of the built environment sector in delivering green cities and a green economy. Sustainability, 7(7), 9417-9443.

Newton, P., \& Taylor, M. (Eds.). (2019). Precinct design assessment: A guide to smart sustainable low carbon urban development. CRC for Low Carbon Living. 
Newton, P., \& Thomson, G. (2017). Urban regeneration in Australian cities. In P. Roberts, H. Sykes, \& R. Granger (Eds.), Urban regeneration: A handbook (Rev. ed., pp. 228-313). SAGE.

Newton, P., Murray, S., Wakefield, R., Murphy, C., Khor, L.-A., \& Morgan, T. (2011). Towards a new development model for housing regeneration in greyfield residential precincts. Final Report 171. Australian Housing and Urban Research Institute.

Newton, P., Plume, J., Marchant, D., Mitchell, J., \& Ngo, T. (2018). Precinct Information Modelling: A new digital platform for integrated design, assessment and management of the built environment. In A. X. Sanchez, K. D. Hampson, \& G. London (Eds.), Integrating information across the built environment industry (pp. 111-132). Routledge.

PCA. (2020). Principles of successful precincts. Property Council of Australia.

Plume, J., Marchant, D., \& Mitchell, J. (2019). Precinct Information Modelling: An emerging platform for integrated precinct scale modelling. In P. Newton \& M. A. P. Taylor (Eds.), Precinct design assessment: A guide to smart sustainable low carbon urban development (pp. 190-202). CRC for Low Carbon Living.

Sharma, R., \& Newman, P. (2020). Land value capture tools: Integrating transit and land use through finance to enable economic value creation. Modern Economy, 11(4), 938-964. https://doi.org/10.4236/me.2020.114070

Thomson, G., Newton, P., \& Newman, P. (2017). Urban regeneration and urban fabrics in Australian cities. Journal of Urban Regeneration and Renewal, 10(2), 169-190.

Open Access This chapter is licensed under the terms of the Creative Commons Attribution 4.0 International License (http://creativecommons.org/licenses/ by/4.0/), which permits use, sharing, adaptation, distribution and reproduction in any medium or format, as long as you give appropriate credit to the original author(s) and the source, provide a link to the Creative Commons licence and indicate if changes were made.

The images or other third party material in this chapter are included in the chapter's Creative Commons licence, unless indicated otherwise in a credit line to the material. If material is not included in the chapter's Creative Commons licence and your intended use is not permitted by statutory regulation or exceeds the permitted use, you will need to obtain permission directly from the copyright holder.

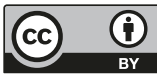

